\title{
CREATION AND DEVELOPMENT OF TEACHER PROFESSIONAL LEARNING COMMUNITY: INSTITUTIONAL FACTORS
}

\author{
Justinas Monkevicius \\ Renaldas Čiužas \\ Lithuanian University of Educational Sciences
}

\begin{abstract}
The article presents a theoretical and empirical analysis of institutional factors of creation and development of successful teacher professional learning communities. On the basis of the conducted theoretical analysis, institutional factors were systemised and divided into four groups: factors related to organisational culture, to processes, to organisational structure, and factors related to financial and material resources. The empirical research reveals the relevance of theoretically distinguished factors to the practical processes of creation and development of successful teacher professional learning communities. It also singles out new factors that have not been investigated by other scholars and highlights the encountered barriers.
\end{abstract}

Keywords: teacher professional learning communities, creation, development, factors.

\section{Introduction}

The conception of teacher professional learning community (hereinafter TPLC) has been presented by a big number of scholars. DuFour, DuFour and Eaker $(2008$, p. 14) state that ,we define a professional learning community as educators committed to working collaboratively in ongoing process of collective inquiry and action research to achieve better results for the students they serve. Professional learning communities operate under the assumption that the key to improved learning for students is continuous, job-embedded learning for educators".

Many researchers determine this community through its performed role. L. Stoll, KLouis (2007) emphasise that such community is the main factor that shapes school policy and practice; R. Linder (2012) points out that it is an efficient, long-term strategy that encourages teachers' professional development; R. Webb et al. (2009), C. Schechter (2012) indicate that this is a strategy for improvement of school students' learning achievements, strengthening of teachers' commitment to their school, for enhancement of their satisfaction with 
Justinas Monkevicius, Renaldas Čiužas. creation and development OF Teacher professional learning community: institutional factors

teacher's work and improvement of efficiency of collective efforts. According to C. Schechter (2012), the activities of TPL Creorganise the school into an interactive field of professional networks.

Determining the concept of TPLC, scholars also provide the description of activity peculiarities (Al-Taneiji, 2009; Linder, 2012; Schechter, 2012; Sigurðardóttir, 2010), others single out peculiarities of its activity culture (Nedzinskaite, 2016; Balyer et al., 2015; Webb et al., 2009).

Some researchers perceive TPLCas a preferred strategy for school reform (Little, 2008; Hord, 2008;2 009; Johnson, 2011), as a new school culture, which eliminates teachers' isolation and lack of concordance of separate strategies for school development (Schmoker, 2005a; Schmoker 2005b; Rasberry \& Mahajan, 2008), as a powerful access to professional development and increase in teachers' effectiveness (Hord, 2009; Stegall, 2011) and as a strategy for promotion of teachers' leadership (Rasberry \& Mahajan, 2008).

The analysis of scientific sources revealed that the majority of authors analysed the concept and features of TPLC (Clark, 2012; Bullought \& Bough, 2008; Tett \& Fyfe, 2010; Whitford \& Wood, 2010; Shevelar \& Westoby, 2012; Hord, 2009, and others), activity of such communities, its results and efficiency (Hord, 2009). However, the factors of TPLC creation and development have received little attention so far.

Most frequently scholars put forward theoretical assumptions about factors of TPLC creation and development not substantiating them on any scientific studies. Therefore, the problem question is raised in the article: what institutional (related to school as an organisation) factors predetermine successful creation and development of TPLC?

The object of research: institutional factors of TPLC creation and development.

The goal of research: to reveal institutional factors of successful creation and development of TPLC.

The objectives of research:

1. to theoretically substantiate and systemise institutional factors of TPLC creation and development.

2. to reveal institutional factors that foster TPLC creation and development.

The methods of research data collection: review of scholarly literature, analysis of educational documents, oral semi-structured individual interview.

The methods of research data analysis: qualitative research strategy applying the grounded theory. 


\section{Theoretical Framework}

The conducted analysis of scholarly literature and educational documents allowed to reveal the factors of TPL Ccreation and development, which are classified into four groups: external factors (related to educational policy, social partnerships and networks); institutional; personal, interpersonal and managerial factors related to school principal's activities; personal, interpersonal and professional factors related to teachers' activities. Considering the goal of the article, a group of institutional factors, which are distinguished by scholars as one of the most important while establishing TPLC at school, are analysed. This group consists of factors related to organisational culture, related to processes, related to financial and material resources (Table 1).

The majority of authors emphasise the importance of the factors of TPLC creation and development at school, which are related to school culture: the climate of democratic participation at school (Boyd \& Hord, 1994); trust-based school culture, which is of utmost importance to an open, reflective professional dialogue (Balyer, Karatas, \& Alci, 2015; Morrow, 2010); culture of collaboration and continuous learning (Johnson, 2011; Hord, 1997).

Researchers also emphasise a whole range of factors of TPLC creation and development that are related school processes. Out of six prerequisites for successful TPLC creation distinguished by D. Johnson (2011, three are assigned to an institutional level. The first prerequisite refers to school mission and vision that is focused on learning and that all the community members are committed to; another prerequisite embraces collective inquiry carried out by collaborating teams searching for most effective impact on school students' academic achievements; the third prerequisite is directly related to TPLC and concerns a constant search for better ways to achieve the goals established by TPLC earlier in the process. The research conducted by V. Boyd and S. Hord (1994) disclosed one more institutional factor, i.e., shared power and decision making among all the members of school community (administrative staff, teachers, other staff members, learners and their parents). Researchers also singled out the factor of collaboration between school administration and teachers, which promotes TPLC creation and development, helps to make decisions about issues related to school students' education and provision of support to them increasing their learning achievements (DuFour, Eaker, \& DuFour, 2005; Fullan, 2001; Strahan, 2003; Bush, 2015). According to R. DuFour (2007, the conception of TPLC alone does not bring a prompt improvement in school activities; on the other hand, it creates efficient and conceptually grounded guidelines for school transformations at all levels, if the whole society mobilises and conducts activities from the start to the end. 
Justinas Monkevicius, Renaldas Čiužas. creation and development OF Teacher professional learning community: institutional factors

A significant attention of numerous scholars is allocated to structural school factors, which contribute to promotion of TPLC creation and development. It is important to create structures, systems, procedures and to devise timetables that nurture collaboration (Boyd \& Hord, 1994; Marzano, 2003), information (Balyer, Karatas, \& Alci, 2015), accessibility of data related to school students' learning, procedures of feedback provision (Balyer, Karatas, \& Alci, 2015). It is also necessary to allocate additional time to teachers (Balyer, Karatas, \& Alci, 2015; Huffman \& Hipp, 2003; Al-Taneiji, 2009; Hirsh, 2004), to provide places with necessary technical conditions for collaboration (Huffman \& Hipp, 2003; AlTaneiji, 2009; Hord, 1997). Moreover, the significance of a system for promotion of teachers' professional development established in a school is also emphasised (Marzano, 2003; Morrow, 2010; Bush, 2015).

J. Huffman and K. Hipp (2003) draw their attention to the fact that the majority of schools, where TPLC were established, had to restructure strategies of school time planning, financing, and/or procedure for substitution a teacher in the classroom providing for additional financing resources.

\section{Table 1 Institutional factors of TPLC creation and development}

\begin{tabular}{|c|c|}
\hline $\begin{array}{c}\text { Related to } \\
\text { organisational } \\
\text { culture }\end{array}$ & $\begin{array}{l}\text { 1. The created climate of democratic participation (Boyd \& Hord, 1994). } \\
\text { 2. The created trust-based school culture (Balyer, Karatas, \& Alci, 2015; } \\
\text { Morrow, 2010). } \\
\text { 3. The created collaboration culture (Johnson, 2011). } \\
\text { 4. The created continuous learning culture (Johnson, 2011; Hord, 1997). }\end{array}$ \\
\hline $\begin{array}{l}\text { Related to } \\
\text { processes }\end{array}$ & $\begin{array}{l}\text { 1. School students' learning-focused school mission and vision that all } \\
\text { community members are committed to (Johnson, 2011). } \\
\text { 2. Power and decision making shared among community members } \\
\text { (Boyd \& Hord, 1994). } \\
\text { Collaboration of school administration and teachers (DuFour, Eaker, \& } \\
\text { DuFour, 2005; Fullan, 2001, and others). } \\
\text { 3. A community of educators committed to working collaboratively in } \\
\text { ongoing processes of collective inquiry and action research to achieve } \\
\text { better results for the students the educators serve (Johnson, 2011). } \\
\text { 4. Collective efforts to implement changes from the beginning to the end } \\
\text { (DuFour, 2007). } \\
\text { 5. A constant search for better ways to achieve the goals that the TPLCs } \\
\text { established earlier in the process (Johnson, 2011). }\end{array}$ \\
\hline $\begin{array}{c}\text { Related to } \\
\text { structure of } \\
\text { organisations }\end{array}$ & $\begin{array}{l}\text { 1. The created structure of collaboration and information and scheduled } \\
\text { meetings (Marzano, 2003; Balyer, Karatas, \& Alci, 2015). } \\
\text { 2. Allocation of additional time (Al-Taneiji, } 2009 \text { and others). } \\
\text { 3. The established local and technical conditions for efficient collaboration } \\
\text { (Huffman, Hipp, } 2003 \text { and others). }\end{array}$ \\
\hline
\end{tabular}




\begin{tabular}{|c|l|}
\hline & $\begin{array}{l}\text { 4. The created system of accessibility of documents regarding school } \\
\text { students' learning (Balyer, Karatas, \& Alci, 2015). } \\
\text { 5. The established mechanisms and procedures of constructive feedback } \\
\text { (Balyer, Karatas, \& Alci, 2015). } \\
\text { 6. The created innovative system focusing on higher opportunities for } \\
\text { professional development, addressing needs of teachers and the school } \\
\text { and responding to the national educational guidelines and scientific } \\
\text { progress (Bush, 2015 and others). }\end{array}$ \\
\hline $\begin{array}{c}\text { Related to } \\
\text { financial and } \\
\text { material } \\
\text { resources }\end{array}$ & $\begin{array}{l}\text { 1. Restructuring of financing (Huffman \& Hipp, 2003). } \\
\text { 2. Allocation of additional financial resources (Huffman \& Hipp, 2003). }\end{array}$ \\
\hline
\end{tabular}

\section{Research Methodology}

The sample of research and selection method: 13 teachers, school principals and deputy principles working in nine Lithuanian schools participated in the research. The participants were selected following the principle of targeted sampling on the basis of experts' recommendations about functioning of TPLC in those schools. Attempts were made to include schools of different levels (1 primary, 2 basic, 2 progymnasiums and 4 gymnasiums) and informants with different positions at school ( 8 subject teachers, 1 deputy principal and 4 school principals). The sampling is also based on the theory of theoretical saturation, when the interviews are conducted data until no new thoughts appear that do not coincide with the ones in the previous interviews.

The ethics of research: 13 informants provided their oral agreement to participate in the research, expressed their wish to be interviewed at convenient to them time at their working place or in Lithuanian University of Educational Sciences. The rules of confidentiality were observed during the interview and responses of the informants were encoded in letters and numbers. The informants were familiarised with the theme, problem, aim and kind of the research.

The method of data collection: the research was carried out from 1 to 30 of October 2016, the method of semi-structured interview (Rupšienè, 2007) was applied for data gathering. The oral interview was conducted individually and lasted approximately $60 \mathrm{~min}$. While interviewing the researcher not always observed the sequence of questions and switched their order (Rupšienè, 2007). Taking into consideration the situation and the completeness of information provided by the informant, the researcher asked additional and correcting questions (Rupšienè, 2007). The methodology and procedures of the interview were prepared and conducted in line with the requirements of the grounding strategy of qualitative research. 
Justinas Monkevicius, Renaldas Čiužas. creation and development OF Teacher professional learning community: institutional factors

The method of data analysis: the grounding theory was applied for data processing. The data analysis was carried out in several stages (Corbin \& Strauss 2008, 159-160). The transcribed interview was analysed applying open, axial and selective coding, which allowed to single out the most important categories. The researcher conducted the open coding of the interview in the first stage. Then all the possible meanings of open coding concepts were reviewed and reflected. In the second stage the reviewer carried out axial coding, when he repeatedly reviewed primary codes, which were combined into larger units. In the stage of selective coding the researcher distinguished the concepts of higher level, i.e. factors of TPLC creation and development, devising a generalised scheme of factors. The data reliability was ensured applying triangulation of different data sources (teachers, deputy principals and school principals expressed their attitude towards factors of TPLC creation and development). Moreover, two experts reviewed the sub-categories and categories distinguished by the researcher discussing the meaning of the gathered data.

The instrument of data collection: the questionnaire for semi-structured individual interview was designed on the basis of factor groups (external; institutional; factors related to school principal activity; and teacher activity) singled out after the analysis of scholarly literature and legal documents. Seeking to identify the variety of all the four group factors, two questions were formulated for each group. One of them referred to promotion of TPLC creation and development and the other focused on obstacles. Next to the aforesaid interview questions, an introductory question was also presented seeking to identify the opinion of the research participants about TPLC in their school.

\section{Findings}

After the theoretical analysis and the empirical research, the biggest number of factors relevant to TPLC creation and development were identified in the group of institutional factors. The most important factor related to organisational culture is "The created collaboration culture". The varied comments of the informants on its expression and impact on TPLC creation and development were expressed using the following sub-categories: "Informal meetings for groups in different spaces", "Constant collaboration initiated by teachers", "Teacher-initiated groups for solving school problems", "Constant collaboration with teachers of other subjects improving practices of learners' education", "Constant collaboration of subject teachers seeking integration of subjects". The informants emphasised the importance of both formal and informal communication of teachers, teacher initiated groups to address school problems or challenges encountered by several teachers, focus of all teacher activities on improvement of learners' achievements. For example the informant (I7) states: "Our aim is to achieve as high learning 
outcomes as possible. We are already convinced that one teacher cannot do anything if the whole team is not involved". The significance of the factor "The created climate of democratic participation" is also high. All the other factors of this area attracted less attention from the informants. Moreover, the informants pointed out several obstacles expressed in the following sub-categories: "Fear of being criticized", "Lack of openness to problems", which reveals the high relevance of trust-based culture to TPLC creation and development.

The factors related to school processes were evaluated as highly relevant: commitment of all the community members to the school mission and vision; research on education practice conducted by collaborating teams; collective efforts to implement changes. The informants paid the same considerable attention to all the abovementioned factors. It allows to conclude that this group of factors establishes essential prerequisites for TPLC creation and development. Actually, the informants did not mention a specific factor: "A constant search for better ways to achieve the goals that the TPLCs established earlier in the process". This proves that TPLCs are already being established at schools but their activities are often identified with those of a learning organisation, whereas knowledge of TPLC possessed by teachers and administrative staff members is limited. Next to the institutional factors related to school processes identified during the theoretical and document analysis, the informants distinguished several nationally relevant factors. The first was "Competition with other schools, and inside the school", which was divided into the following sub-categories: "An ambition to become the best school" and "Competition inside the school seeking better school learners' achievements". Informant T6 points out: "Nobody directly points at it but I think that there is psychological competition for school learners' achievements, which becomes obvious during state maturity examinations". On the other hand, the informants expressed varied evaluation of this factor. Some of them referred to it as contributing to mobilisation, whereas others saw it as impeding formation of collaborating groups. The sub-category "Teachers' competition for teaching load" has to be singled out as well. It is presented in the research as an example of negative internal competition: "Teachers of our school see other colleagues teaching the same subject as competitors in fight for teaching load. The number of children is decreasing and, instead of mobilising its members and trying to take over children from other schools and invite them to learn in our school, teachers engage in rivalry with each other and in numerous intrigues" T2. The factors newly distinguished by the informants are named as "Collaboration together searching for appropriate solutions to educational problems" and "Collaboration of teachers with other school employees and teachers".

School structure-related factors received considerable attention of the informants. This proves that TPLC sare established and function in the schools, where conditions are transformed and adapted to such conditions. The factor "The 
Justinas Monkevicius, Renaldas Čiužas. creation and development OF Teacher professional learning community: institutional factors

created structure of collaboration and information and scheduled meetings" was commented most extensively. As many as10 sub-categories that reveal the conditions necessary for TPLC activities were distinguished: "Established information structure", "Formal structural units encouraging teachers' informal collaboration", "Formal time during meetings for reaching agreements", "Time dedicated for observation of colleagues lessons", "Flexible changes in timetables to create conditions for teacher learning from each other", "Adjusting of timetables to innovative forms of teaching", "Adjusting of timetables to school learners' convenience", "Coffee breaks as time for informal meetings of teachers", "Informal meetings during breaks", "Meetings during school learners' holidays". The informants particularly stress the possibility of meeting and discussing various problems: "We have such a possibility to meet, when once a week, on Thursdays, the second lesson for us (teachers of 3rd forms) is free and we gather in my classroom. <...> The timetable is drawn up to enable teachers to meet" I9. The informants also see "No scheduled time for meeting" as a serious drawback: "The possibility of meeting during other breaks (not the long ones) exists only if you shorten your lessons. We all finish at very different times $<\ldots>$ and there is no day, when all teachers are able to meet" I7. The participants did not mention the factor "The created system of accessibility of documents regarding school students' learning", which, according to the researchers Balyer, Karatas, Alci, (2015), is important to TPLC activities at school. The school communities are not likely to have encountered such systems and they are not aware of the usefulness solving problems related to school students' learning and achievements.

The informant singled out two new factors linked to school structure. One of them refers to an attempt to change formal activities of methodological groups into a voluntary space of teacher team learning: "Voluntary, efficient involvement of teachers in activities of methodological groups". According to the informants, another contradictory factor is: "Teaching in classrooms designated for separate subjects". Some informants interpret the system as a factor that facilitates teacher isolation: "I think if we had a system of classrooms for separate subjects and each teacher had his/her classroom, they would communicate less frequently than now" I7, whereas others see it as a place for informal meetings: "if there is a need, we more frequently in the classroom of one or another teacher. $\langle\ldots\rangle$ This satisfies us perfectly ... "I13. The informants also pointed out the obstacles related to teacher communication and age, which were expressed in the following subcategories: "Teachers do not allocate personal time to communication", "Virtual communication replaces real communication" and "Experienced senior teachers do not want to develop professionally".

The factors of TPLC creation and development that are linked to school financial and material resources did not receive significant attention from the 
informants, who only emphasised "Insufficient financing of professional development". Thus, the informants evaluate school financing as a factor that impedes opportunities rather than the one opening up them.

\section{Conclusions}

The analysis of scientific literature and educational documents revealed that four groups of internal factors are relevant to TPLC creation and development at school: factors linked to school culture, processes, structure and financial and material resources.

The empirical research, which aimed to identify factors that promote TPLC creation and development, highlighted several aspects. Firstly, the majority of theoretically distinguished factors coincide with the ones indicated by the informants, i.e., they are relevant to TPLC creation and development. According to the informants, the factors related to school culture are the most relevant: school microclimate based on collaboration and democratic participation. The most significant factors related to school processes are as follows: commitment of all the community members to school mission and vision; collaboration of school administration and teaches; research on educational practice conducted by collaborating teams; collective efforts to implement changes. The following most significant school structure-related factors were distinguished: the created structure of collaboration and information, scheduled meetings; allocation of additional time; location and technical conditions for collaboration; created mechanisms and procedures of constructive feedback.

Secondly, more factors that are significant to TPLC creation and development were revealed in the national education context compared to the ones identified during the theoretical analysis: a) voluntary, efficient involvement of teachers in activities of methodological groups (a school structure-related factor); b) collaboration searching for appropriate solutions to educational problems together (a school process-related factor).

Thirdly, several contradictory factors were distinguished: competition with other schools; competition inside the school; system of classrooms designated for separate subjects at school, which either can facilitate teachers involvement in TPLC or to increase their isolation.

The qualitative research on factors relevant to TPLC creation and development allowed to prepare a comprehensive description of factors. However, assessment of the strength of factor impact and identification of the most relevant factors require further quantitative research. 
Justinas Monkevicius, Renaldas Čiužas. creation and development OF Teacher professional learning community: institutional factors

\section{References}

Al-Taneiji, S. (2009). Professional Learning Communities in the United Arab Emirates Schools: Realities and Obstacles. International Journal of Applied Educational Studies. Dec2009, 6 (1), 16-29. 14p. 2 Charts.

Balyer, A., Karatas, H., \& Alci, B. (2015). School Principals' Roles in Establishing Collaborative Professional Learning Communities at Schools. Procedia - Social and Behavioral Sciences, 197(February), 1340-1347. http://doi.org/10.1016/j.sbspro. 2015.07.387

Boyd, V., \& Hord, S. M. (1994). Schools as Learning Communities. Issues ... about Change, 4 (1), (N/A).

Bullough, R. V., \& Baugh, S. C. (2008). Building Professional Learning Communities Within a University-Public School Partnership. Theory Into Practice, 47 (4), 286-293. http://doi.org/10.1080/00405840802329169

Bush, N. L. (2015). The evolution of a professional learning community in a professional development school: an ethnographic case study. Ashland University.

Clark Jr., E. T. (2012). Designing Schools as Learning Communities. Encounter. Spring2012, $25(1)$.

Corbin, J., \& Strauss, A. (2008). Basics of Qualitative Research. Techniques and Procedures for Developing Grounded Theory. 3rd edition. Thousand Oaks: SAGE.

DuFour, R., Eaker, R., \& DuFour, R. (2005). Closing the Knowing-Doing Gap. In R. DuFour, R. Eaker, \& R. DuFour (Eds.), On Common Ground: The Power of Professional Learning Communities. Bloomington: National Educational Service.

Dufour, R. (2007). Professional Learning Communities: A Bandwagon, an Idea Worth Considering, or Our Best Hope for High Levels of Learning? Retrieved from http://www.nmsa.org/Publications/MiddleSchoolJournal/Articles/September2007/Articl e1/tabid/1496/Default.aspx

Fullan, M. (2001). Leading in a Culture of Change. San Francisco: Jossey-Bass.

Hirsh, S. (2004). Professional development works best embedded in improvement plans. National staff development council, 25 (1), 12-16.

Hord, S. M. (2009). Professional learning communities. National staff development council, 30 (1), 40-43.

Hord, S. M. (1997). Professional Learning Communities: Communities of Continuous Inquiry and Improvement. Austin: Southwest Educational Development Laboratory. Retrieved from http://www.sedl.org/pubs/change34/

Hord, S. M. (2008). Evolution of the Professional Learning Community: Revolutionary Concept Is Based on Intentional Collegial Learning. Journal of Staff Development, 29 (3), 10-13.

Huffman, J., \& Hipp, K. (2003). Reculturing schools as professional learning communities. Lanham, MD: Scarecrow Education.

Johnson, D. R. (2011). A Quantitative Study of Teacher Perceptions of Professional Learning Communities' Context, Process, and Content. Seton Hall University. Retrieved from http://scholarship.shu.edu/dissertations

Linder, R. A. (2012). Professional Learning Communities: Practices for Successful Implementation. Delta Kappa Gamma Bulletin. Spring 2012, 78 (3).

Little, J. W. (2008). Declaration of interdependence. National staff development council, 29 (3), $53-56$. 
Marzano, R. J. (2003). What works in schools: Translating research into action. Alexandria: Association for Supervision and Curriculum Development.

Marzano, R. J., Waters, T., \& McNulty, B. A. (2005). School Leadership That Works. Aurora, Co: Mid-continent Research for Education and Learning.

Morrow, J. R. (2010). Teachers' perceptions of professional learning communities as opportunities for promoting professional growth. Appalachian State University.

Rasberry, A. M., \& Mahajan, G. (2008). From Isolation to Collaboration: Promoting Teacher Leadership Through PLCs. North Carolina: The Center for Teaching Quality. Retrieved from https://www.mendeley.com/viewer/?fileId=4754f9ef-7f84-552d-6131-f31409215f 0a\&documentId=cdf95ed6-d003-36e0-8773-c48ab1d445e3

Rupšienè, L. (2007). Kokybinio tyrimo duomenu rinkimo metodologija. Klaipėda: Klaipėdos universiteto leidykla.

Schmoker, M. (2005). No Turning Back: The Ironclad Case for Professional Learning Communities. In R. Eaker \& R. DuFour (Eds.), On Common Ground: The Power of Professional Learning Communities (pp. 135-154). Bloomington: National Educational Service.

Schmoker, M. (2005). Here and Now: Improving Teaching and Learning. In R. DuFour, R. Eaker, \& R. DuFour (Eds.), On Common Ground: The Power of Professional Learning Communities (pp. xi-xvi). Bloomington: National Educational Service.

Sigurðardóttir, A. K. (2010). Professional Learning Community in Relation to School Effectiveness. Scandinavian Journal of Educational Research, 54 (5), 395-412. http://doi.org/10.1080/00313831.2010.508904

Stegall, D. A. (2011). Professional learning communities and teacher efficacy: a correlational study. A Dissertation Doctoral Program in Educational Leadership.

Stoll, L., \& Louis, K. S. (2007). Professional Learning Communities Divergence, Depth and Dilemmas.

Strahan, D. (2003). Promoting a Collaborative Professional Culture in Three Elementary Schools That Have Beaten the Odds. The Elementary School Journal, 104 (2), 127-146.

Tett, L., \& Fyfe, I. (2010). Community Education, Learning and Development. Edinburgh: Dunedin Academic.

Webb, R., Vulliamy, G., Sarja, A., Hämäläinen, S., \& Poikonen, P. (2009). Professional learning communities and teacher well-being? A comparative analysis of primary schools in England and Finland. Oxford Review of Education, 35 (3), 405-422.

Whitford, B. Lou, \& Wood, D. R. (2010). Teachers Learning in Community: Realities and Possibilities. NY: SUNY Press. 